\title{
IMPACT OF ADDING OXYGENATES TO DIESEL FUEL ON ENGINE'S PERFORMANCE AND EMISSIONS
}

\author{
Marwa Naji Kareem
}

me.17.01@grad.uotechnology.edu.iq,_adel196150@Yahoo.com

\begin{abstract}
Experimental investigation of performance and emission of conventional a four-stroke, single-cylinder direct injection (DI) diesel engine at variable engine speed range from (1500 to $3000 \mathrm{rpm}$ ), carried out at steady-state tests conditions with diesel fuel and biodiesel which is produced from sun flower oil mixed with the higher alcohol. The blends effects on the performance and emission for the blended fuels measured and compared. $10 \%$ and $15 \%$ of Pentanol, Octanol added to the biodiesel blended with diesel for various test conditions. The experimental results showed an approximately $2-9 \%$ increase in the brake-specific fuel consumption (BSFC) for the prepared blends of pentanol and octanol due to the lower heating value (LHV), with higher brake thermal efficiency compared to diesel fuel. With expressively reduction of $(9.8-21 \%$ vol.) in carbon monoxide (CO), and total unburned hydrocarbons (THCs) of (65-78.3\% ppm), and nitric oxides (NOx) (44.4-52.9\% ppm). The combustion analyses showed that the addition of biodiesel to conventional diesel fuel decreased the ignition delay and reduced the properties. These results indicated that biodiesel and higher alcohol could be used without any engine modifications as an alternative and environmentally friendly fuel.
\end{abstract}

Key words: Higher alcohol, Sunflower oil biodiesel, Pentanol, Octanol, Engine performance, Pollution.

$$
\text { تأثير إضافة الوقود الطويل السلسلة إلى الديزل على أداء المحرك واتبعاثاته }
$$

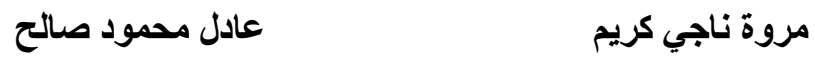

الخلاصة

فحص تجريبي للادداء وانبعاث محرك ديزل بعمل بنظام الحقن المبانشر أحادي الأسطو انة رباعي الأشو اطبسر عات متغيرة

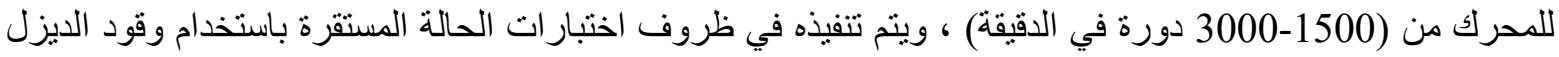

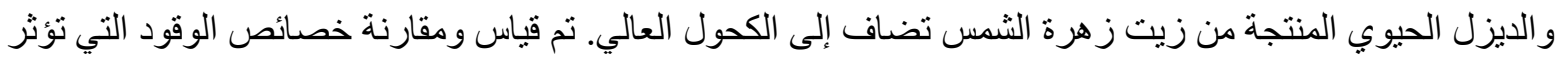

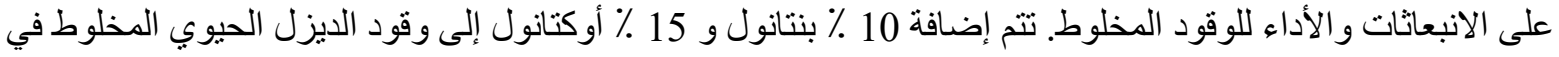

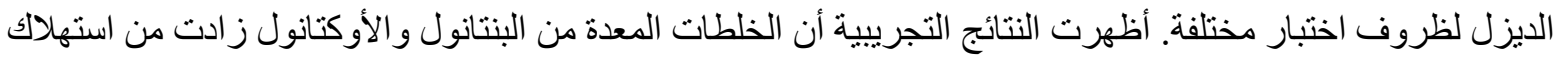

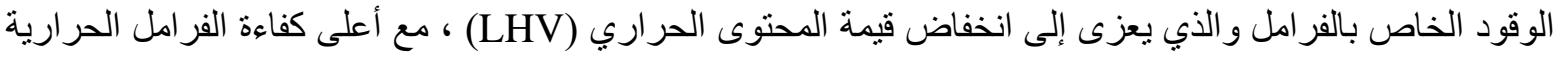

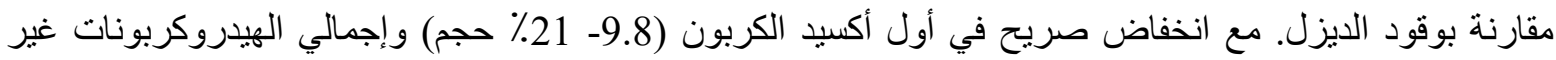

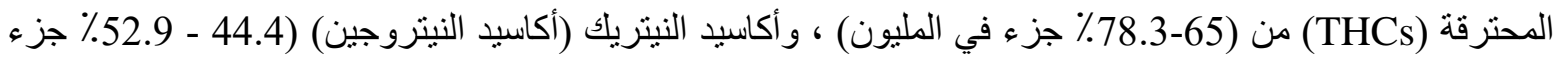

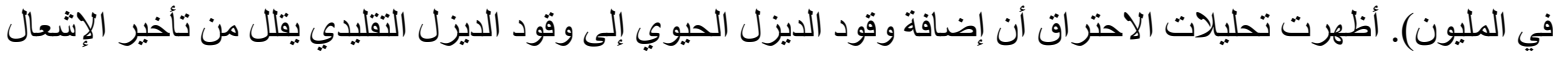

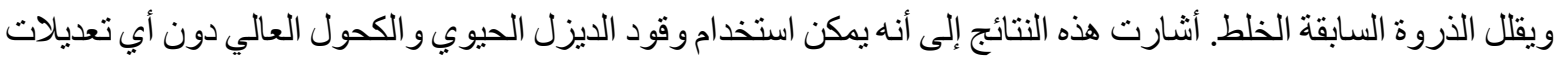
في المحرك كوقود بديل وصديق للبيئة. الكلمات المفتاحية: الكحول الطويل السلسلة ، وقود الديزل الحيوي لزيت عباد الثمس ، البنتانول ، الأوكتانول ، أداء

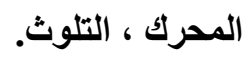




\begin{tabular}{|c|c|}
\hline \multicolumn{2}{|c|}{ NOMENCLATURE: } \\
\hline $\mathrm{BP}_{\mathrm{P}}$ & Brake power \\
\hline BSFC & Brake specific fuel consumption \\
\hline SME & Sun flower methyl ester \\
\hline $\mathrm{CO}$ & Carbon monoxide \\
\hline $\mathrm{CO} 2$ & Carbon dioxide \\
\hline $\mathrm{HC}$ & Hydrocarbon \\
\hline NOx & Oxides of nitrogen \\
\hline rpm & Revolution per minute \\
\hline LHV & Lower heating value \\
\hline DI & Direct injection \\
\hline B & Biodiesel fuel \\
\hline $\mathrm{D}$ & Diesel fuel \\
\hline OCT & Octanol \\
\hline PEN & Pentanol \\
\hline
\end{tabular}

\section{INTRODUCTION}

In the 20th century, world energy usage has increased significantly due to the effect of industrialization, and this increase in usage has resulted in inadequate petroleum reserves, such as in the 1970s oil crisis. All of these problems have motivated the scientific society to seek new, alternative energy sources that have decreased global warming and pollution effects. At this point, the scarcity of known petroleum reserves and increasing environmental consciousness has made renewable energy sources more attractive (Arindam Dasal et al. 2017). In such matter, investigations on the renewable substituted fuels, as alcohols and biodiesel for the diesel engines go on increasingly. Nevertheless, pure biodiesel cannot employed merely in the diesel engines owing to its high viscosity and density. Thus, to enhance the viscosity and density of a biodiesel blend, alcohols are utilized as fuel additive (Emiroğlu and Şen 2018). (Li et al. 2015) studied experimentally the influences of pentanol addition to the diesel-biodiesel blends for evaluating the diesel engine performance and emission. It was inferred that the pentanol indicated a greater thermal efficiency than that for the mineral diesel for testing loads range of $(0.5 \mathrm{MPa})$ to $(1.0 \mathrm{MPa})$. A clear reduction in the emissions of soot also, reached by pentanol addition. The (NOx) emissions at the same time decreased in comparison with the pure diesel fuel utilization using low to middle loads. The diesel engine that was fueled with the oxygenated fuel blends is able to reduce the emissions of $(\mathrm{CO})$ and the unburned whole (HC), except for diesel-pentanol blends at a lower load of engine. (Chaichan 2015) focused on the trade-off between NOx and PM emitted from an diesel engine fueled by ethanol and methanol-diesel blends. The results elucidated that the concentration of (PM) decreased without considering the oxygenating additives' kinds and it reduced with the oxygen mass fraction increment in blends without (NOx) increase. The concentrations of emitted (PM) from the diesel engine raised when was fueled with pure diesel fuel and provided with (EGR). The operation of engine upon the diesel-oxygenate blends presented a considerable decrease in the concentrations of (PM) and (NOx) and PM.

Chaichan et al 2014 investigated the influences of bioethanol-diesel blends and exhaust gas recirculation (EGR) on the engine performance and emissions. The practical experiments done by using a fixed ethanol blend ratio (10\% ethanol $+90 \%$ diesel) and three EGR ratios $(10 \%, 20 \%$ and $30 \%)$. The engine operation with bioethanol-diesel blend and EGR reduced the NOx concentration remarkably and engine noise, but increased the $\mathrm{HC}$ and $\mathrm{CO}$ concentrations. Ethanol existence contributed in reducing the EGR effects, and limited the increments in the $\mathrm{HC}$ and $\mathrm{CO}$ concentrations. 
(Li et al. 2014)studied the diesel engine performance characteristics, which fueled with diesel blends and pentanol. It was obtained to increase the thermal efficiency and reducing the specific fuel consumption, due to time restrictions for fuel injection provided through the fuel pentanol mixture. The results revealed that the NOx and soot emissions decreased significantly for pentanol. (Zhang and Balasubramanian 2014) evaluated experimentally the potential impact of diesel-biodiesel-butanol blends on the engine performance with physical, chemical and toxicological properties of the particulates emitted. The results evinced a border variation in BSFC until (10\%) addition of butanol, and an enhancement in BTE at the medium and higher loads of engine. In comparison with B20, also, the addition of butanol exhibited the emission of the lower overall particle-phase polycyclic aromatic hydrocarbons (PAHs), lower carcinogenic capability, and lower cytotoxicity of particle extracts, in comparison with those of (B20). (Yasin et al. 2013) examined experimentally the influence of the ternary fuel blend (methanol-biodiesel-mineral diesel) on the diesel engine performance and emissions. The outcomes revealed that the existence of alcohol assists to decrease the concentration of the density and viscosity of biodiesel as mixing with the mineral diesel. With active increasing in cetane number. Results from an increment in the concentration of alcohol in biodiesel blend fuels. It was notice that the ternary fuel blend decreased the emissions of (CO) with increasing the (BSFC) and the emissions of (NOx). (Saleh 2013) investigated experimentally the performance of a single cylinder C.I. engine that fueled with various ethanol blends added to the diesel fuel. The increment in the ethanol proportion in the blend improved the (SFC) at each certain load, while the (BTE) for the diesel engine is greater than the one for the dual fuel engine at lower and medium loads, whereas it's less for the higher loads. Generally, the ethanol addition in the blend enhances the efficiency. The impediment of timing of injection of the diesel fuel led to raise the (SFC) constantly to around (40\%) for too late timing. The dual fuel thermal efficiency is generally less than that one for the diesel engine if impeding the timing of injection. (Wang et al. 2012) investigation experimentally the emission of the diesel engine exhaust emissions utilizing an ultra-low-sulfur diesel fuel mixed with the dimethyl ether, ethanol, and biodiesel. The principal outcomes depicted that the emission of particulate matter (PM) reduced with the raised amount of oxygenate of blends, while the addition of ethanol to the diesel fuel raised the emissions of $\mathrm{CO}, \mathrm{HC}, \mathrm{NO}_{2}$, and NOx with redaction in the concentration of the particles number. (Altun et al. 2011) documented that the n-butanol addition to the cottonseed biodiesel blends decreased the (BSFC) of the fuel blends that obtained higher in comparison with that of the traditional diesel fuel, while the n-butanol addition to the (B20) fuel blend resulted in a little increment in the (BSFC) and (BTE) compared to the (B20) fuel blend. Regarding the exhaust emissions, the emissions of $\mathrm{HC}$ and $\mathrm{CO}$ reduced, and emission of (NOx) stayed nearly unvaried at lower loads of engine, whereas it reduced at higher loads, also, the fuel blends caused a steep decrease of smoke opaqueness over the entire range of engine tests. In this study, the effect of the addition pentanol and octanol upon the basic fuel characteristics of the sunflower biodiesel were tested and compared with specified standards. The analysis of the influences of high alcohol used as the biodiesel blend additives upon the diesel engine performance and emission characteristics also conducted and compared with the diesel fuel. The aim of this experimental investigation is to analyze the feasibility of higher alcohol-biodiesel-diesel blends as an alternative for petro-diesel for single-cylinder diesel engines. To fuel ratio, combustion deterioration and efficiency losses largely attributed to the increase of pumping work with the increase of EGR. EGR improves the combustion qualities by increasing the inlet charge temperature, UHC and CO re-burned with using of EGR. 


\section{EXPERIMENTAL WORK}

\section{Equipment}

All experiments achieved on one cylinder, four-stroke, direct-injection, diesel engine having the main specifications listed in Table(1). This engine coupled to a hydraulic dynamometer for controlling the exerted load upon it via raising the torque. The $\mathrm{HC}, \mathrm{NOx}, \mathrm{CO}$, and $\mathrm{CO}_{2}$ concentrations measured via Multi gas mode HG-550 emissions analyzer. A (pneumatic box) with an orifice system was used to measure the amount of air rate using pressure gauge scale (manometer). Engine speed measurements (rpm) conducted using digital tachometer. A fixed size container used to measure the amount of fuel consumed, while thermocouples (type J) used to measure the exhaust gasses temperature. The schematic diagram of the experimental setup depicted in Figure(1) and the test system consisted of an engine, a dynamometer, fuel supply system, Thermocouples, and emission analyzer. The experimental work conducted in the laboratories of the University of Technology.

Equations used in the present study

\section{Brake power}

$$
\mathrm{Bp}=\frac{2 \pi * N * T b}{60 * 1000}
$$

Mass flow rate of air

$$
\begin{gathered}
\dot{\mathrm{m}}_{a}=\frac{5 \sqrt{h_{0}}}{3600} * \rho_{a} \quad(\mathrm{Kg} / \mathrm{sec}) \\
\text { mass flow rate of fuel } \\
\dot{m}_{f}=\frac{V_{f} \times \rho_{f}}{\mathrm{t} \times 10^{6}} \quad(\mathrm{~kg} / \mathrm{sec})
\end{gathered}
$$

\section{Brake spicefic fuel consumption}

$$
\mathrm{bsfc}=\frac{\min f * 3600}{b_{p}}
$$

Brake thermal efficiency

$$
\mathrm{y}_{\mathrm{bth}}=\frac{b p}{\min f * L H V} * 100 \%
$$

Volumetric efficiency

$$
\eta_{\mathrm{v}}=\frac{\text { ma/ } / \rho \mathrm{a}}{\text { vdis } * \mathrm{n} / 60}=100 \%
$$

Ideal mass flow rate of air

$$
\dot{\mathrm{m}}_{\text {air (ideal) }}=\frac{v d i s * n * \rho a}{60}
$$

\section{Fuel}

The fuel used in this work was conventional Iraqi diesel, while biodiesel was made from the raw sunflower oil via using the similar method and steps utilized by (A.M. Liaquat et al. 2013). Four fuel blends were produced, including (10\% biodiesel $+10 \%$ pentanol+80\% diesel), $(15 \%$ biodiesel $+15 \%$ pentanol $+70 \%$ diesel $),(10 \%$ biodiesel $+10 \%$ octanol $+80 \%$ diesel $)$ and ( $15 \%$ biodiesel $+15 \%$ octanol $+70 \%$ of diesel). These blends compared with diesel fuel. The fuels blended by using a homogenizer for $25 \mathrm{~min}$ operated at $3500 \mathrm{rpm}$. The characteristics of diesel fuel, higher alcohol and biodiesel as given in Table(2).

\section{ANALYSIS OF ERROR}

The accuracy of measurement is the reliance potential range of the outcomes of study. The origins of error were identified vie calibration of the utilized equipment of measurement, and the uncertainty in the present study was determined. Table(3) lists the devices of measurement 
with their accuracy of calibration. Thus, uncertainty is obtained by the following equation as (Taylor \& Francis 2007) :

$$
e-R=\left\lceil(\partial \mathrm{R} /(\partial \mathrm{V}-1) \mathrm{e}-1)^{2}+(\partial \mathrm{R} /(\partial \mathrm{V}-2) \mathrm{e}-2)^{2}+\cdots+(\partial \mathrm{R} /(\partial \mathrm{V}-\mathrm{n}) \mathrm{e}-\mathrm{n})^{2}\right\rceil^{0.5}
$$

where,

$e-R$ : The resulted uncertainty

$\mathrm{R}$ is a function consisting of variables, or $\mathrm{R}=\mathrm{R}(\mathrm{V} 1, \mathrm{~V} 2, \ldots, \mathrm{Vn})$.

$\mathrm{e}$ is the variable uncertainty range.

The partial derivative $(\partial \mathrm{R} / \partial \mathrm{V} 1)$ is the resulted single variable's sensitivity. Thus, the uncertainty for the current outcomes of study using equation (1) was:

$$
\begin{aligned}
& e-R=\left[(0.6)^{2}+(1)^{2}+(2)^{2}+(1.3)^{2}+(2.4)^{2}+(0.67)^{2}+(0.82)^{2}+(1.034)^{2}\right. \\
& \left.+(0.003)^{2}\right\rceil^{0.5}=\mp 3.873 \%
\end{aligned}
$$

Figure (2a, b) evince the variation of (BSFC) with the engine speed at the constant load condition for all tested blends. BSFCs for the blends are higher than that of diesel at low engine speeds, but it becomes relatively lower than diesel (BSFC) at high engine speed. The use of pentanol or octanol as additives gave nearly the same results but octanol blends showed relatively lower (BSFC) than pentanol. The alcoholic additives reduced the cetane number of the blend, which means fuel's self-ignition reduction that resulted in longer ignition delay period and lower peak pressure inside the combustion chamber. As a result, the released energy will be lower, which call for more fuel consumption to reach the required engine speed. When the oxygenated share in the blends increased for $30 \%$ the heating value of the blend reduced and ignition delay period increased resulting in higher (BSFC) for these blends than diesel at low and medium speeds. At high speed, the combustion enhanced because of several reasons such as the oxygen content in the blends is high and at high speed, it will compensate the lack of air causing better combustion. The high heat released at high-speed conditions reduces the ignition delay period of the blends, which enhances the resulted combustion characteristics. The use of octanol gave relatively better (BSFC) than the pentanol blend at the same conditions. When comparing between the two proportions added, the use of $20 \%$ of oxygenated additives has lower (BSFC) than adding $30 \%$ oxygenates to diesel. The (bsfc) increased by 7.5\%, 3.4\%, 9\%, and 4\% for D80B10PN10, D80B10OC10, D70B15PN15, and D70B15OC15, respectively, compared to diesel. Figure (3a, b) illustrates the variation of exhaust gas temperatures with the engine speed at the constant load condition for all tested blends. The exhaust gas temperature of diesel fuel was higher than the engine exhaust gasses temperature with tested blends. The addition of alcoholic (octanol and pentanol) fuels gave lower energy content of the fuel blends, low cetane number and higher oxygen content with the higher latent heat of evaporation of the octanol and pentanol blends compared to diesel fuel. The (EGT) decreased by $6.4 \%, 4.4 \%, 9 \%$, and $7.6 \%$ for D80B10PN10, D80B10OC10, D70B15PN15, and D70B15OC15, respectively, compared to diesel. The figure also elucidates that the exhaust temperature reduces with raising the pentanol quantity in blend. The pentanol low energy quantity results in lower temperature of combustion, and D70B15PN15 with the lowest quantity of energy among the whole blends produces the lowest exhaust temperatures at the whole loads of engine. Figure $(4 a, b)$ demonstrates the variation of brake thermal efficiency with the engine speed at the constant load condition for all tested blends. Diesel fuel characterized by lower thermal efficiency when burned and the additives added to improve it. In some cases, the additives increased the thermal efficiency due to the enhancement the atomization and combustion properties of the blends. The figure shows a slight improvement in the efficiency with increasing alcohol ratio; this is due to the oxygen content of alcohol, so that the combustion efficiency enhanced. The 
$\left(\mathrm{n}_{\mathrm{bth}}\right)$ increased by $3.4 \%, 6 \%, 5 \%$, and 10\% for D80B10PN10, D80B10OC10, D70B15PN15, and D70B15OC15, respectively, compared to diesel fuel.

Figure $(5 \mathrm{a}, \mathrm{b})$ illustrates the variation of $\mathrm{CO}$ with the engine speed at the constant load condition for all tested blends. The formation of $\mathrm{CO}$, this is attributed to incomplete combustion and controlled primarily by the fuel/air equivalence ratio with fuel atomization rate. The $\mathrm{CO}$ levels decreased by $9.8 \%, 14 \%, 16 \%$, and $21 \%$ for D80B10PN10, D80B10OC10, D70B15PN15, and D70B15OC15, respectively, compared to diesel. The results showed that the increase in pentanol or octanol content in ternary blends decreased the $\mathrm{CO}$ emission, where the oxygenated fuels increase the air/fuel ratio, higher local oxygen concentration that leads to improve the combustion process with decreasing in $\mathrm{CO}$ emissions. For all fuels, can be observed that the emissions of carbon monoxide decreases with increasing engine speed until it reaches its maximum value at smoke point (Stephen R. Turns 1996). "The addition of oxygen in the blends' contents secures the oxidation of (CO) even in the locally fuel-rich regions, hence assisting to decrease the emissions of (CO)", as Ref.(Li et al. 2015) indicated. Figure (6a, b) illustrates the variation of HC with the engine speed at the constant load condition for all tested blends. The highly important reason behind the (HC) emission is the trapping of the fuel into the crevice volumes of the chamber of combustion into a diesel engine (John B.Heywood 1988). The result indicated that the raised quantity of alcohol in the ternary blends significantly reduced the development of the emissions of (HC), the test engine resulted more emissions of $(\mathrm{HC})$ at low speeds of engine. When the speed rise, the emission reduced for adjusted blends by (43.45\%), and the swirling velocity of air is slow at a low speed of engine, hence resulting in a long delay of ignition. The blending of the ternary blends with air causes an over-rich blend or the combustion reaction quenching and this can cause incomplete products of combustion and high (HC) in the exhaust gases, as manifested by Ref. (John B.Heywood 1988). The emission of (HC) emission for the sunflower oil biodiesel decreases with the rise of the octanol quantity. Via appending the octanol to the sunflower oil biodiesel at $(10 \%)$ and $(20 \%)$ on volume, the HC emissions reduced by $5.1 \%$ and $5.7 \%$ as a consequence of better combustion efficiency, as indicated by references(Rajesh Kumar et al. 2016)(Devarajan et al. 2017). The (HC) decreased by 65\%, $73 \%, 69 \%$, and $78.3 \% \mathrm{ppm}$ for D80B10PN10, D80B10OC10, D70B15PN15, and D70B15OC15, respectively, compared to diesel. Figure $(7 \mathrm{a}, \mathrm{b}$,$) illustrates the variation of$ NOx with the engine speed at the constant load condition for all tested blends. It is notes that the emission of (NOx) for the neat diesel is more than that emitted by tested blends. It is true that these blends have a higher oxygen content, which improves the combustion process and increases the released heat and temperatures inside the combustion chamber in the same trend obtained by M. Sivakumar,et al 2016 and (Venkata Ramanan and Yuvarajan 2016). However, there is another factor that interfered and causes the NOx levels to reduce lower that is the lower heating value of the blends compared to diesel. In addition, the cetane number of the blends is lower than diesel, causing longer ignition period and lower heat released inside the combustion chamber. The last important factor affecting the temperatures inside the combustion chamber is the high vaporization temperature needed by the alcoholic additives to vaporize and mix with air and burn. The resultant of these entire factors is the lower temperatures inside the combustion chamber. As a result, the NOx levels for the tested blends were lower than diesel fuel. The NOx levels reduced by $44.4 \%, 52 \%, 48.4 \%$, and $52.9 \%$ ppm for D80B10PN10, D80B10OC10, D70B15PN15, and D70B15OC15, respectively, compared to diesel.

\section{CONCLUSIONS}


The performance, emissions and different ratios of the properties of alcohol additives (pentanol and octanol) in the diesel-biodiesel blended in a single-cylinder (DI) diesel engine was study with variable engine speed conditions. The comparison between the stylish diesel results and the results of the modified mixtures. The main conclusions drawn from the results of experiments are:

1. Raising the pentanol proportion in the biodiesel blends decreased the viscosity and density considerably despite the Calorific Value of alcohol was less than that of diesel.

2. The rising interest in the alcohol-based biofuels and biodiesel results in searching for a substituted and expanded method for blending the alcohol with the biodiesel and diesel. Due to the superior quality of fuel of high-alcohol (pentanol and octanol), such kind of additive could alleviate the recent difficulties with the utilization of biodiesel fuel.

3. Generally, the octanol and pentanol fuel either impart considerable advantages in the sole form or blend mode, and they yield higher calorific value, better quality of auto ignition and stability of phase in comparison with the lower alcohols. Thus, the fuel consumption to generate the similar power output is not important.

4. Blending of the pentanol and octanol with the biodiesel-diesel leads to a better combustion and performance output due to the presence of higher oxygen content in the octanol and pentanol.

5. The emissions decreased by a significant amount, the NOx emissions there found to decrease, and the $\mathrm{CO}$ emissions also decreased as the use of alcohol percentage in the fuel blend.

6. The addition of higher alcohol to biodiesel-diesel fuel caused a decrease in the (BTE) in comparison with the one for the pure diesel, and the rate of decrease proportionate to the alcohol fraction in blend.

7. The higher fraction of alcohol in blends resulted in an increment in the (BSFC) owing to the decrease in the blend calorific value.

8. The period of the ignition delay becomes longer for the higher blends of alcohol in comparison with the diesel. The properties of self-ignition are influence owing to the lower cetane number of fuel blend, which caused the increment of the period of the ignition delay.

9. At all engine speeds, the exhaust gas temperature of diesel fuel was higher than the tested blends. The cetane number decreased with the alcohol addition, causing insufficient combustion. Hence, the exhaust gas temperature of alcohol-biodieseldiesel blends was lower than the one for the diesel fuel.

Pentanol and octanol are a promising substituted biofuel that manifest a considerable enhancement in the performance, combustion and emission of engine if they are blends, with the biodiesel. Thus, they can be utilizing as additives to the biodiesel-diesel fuel without any modification of engine. 


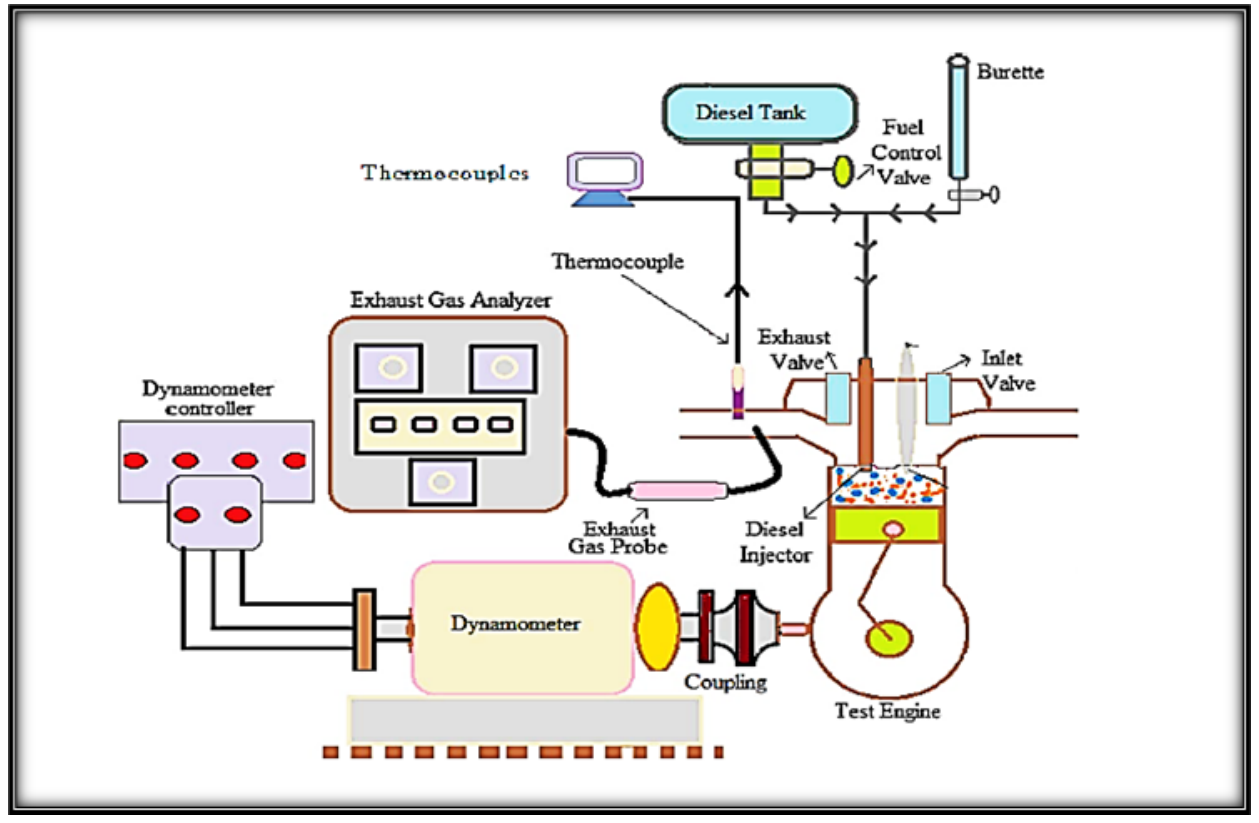

Fig. (1). Schematic diagram of the engine testing setup.

Table(1): Specifications of tests engine

\begin{tabular}{|l|l|}
\hline Type of engine & 1cyl., four strokes \\
\hline Model of engine & $\begin{array}{l}\text { Loben - RB170F/ Rig of diesel } \\
\text { engine }\end{array}$ \\
\hline Displacement & $0.221 \mathrm{~L}$ \\
\hline Bore & $70(\mathrm{~mm})$ \\
\hline Stroke & $55(\mathrm{~mm})$ \\
\hline Compression ratio & 17 \\
\hline Fuel injection & Direct injection \\
\hline Max. Engine speed & $3000-3600(\mathrm{rpm})$ \\
\hline
\end{tabular}

Table (2): Characteristics of the diesel fuel, biodiesel and higher alcohol.

\begin{tabular}{|c|c|c|c|c|c|c|}
\hline Fuel type & $\begin{array}{c}\text { Boiling } \\
\text { point } \\
\left(^{\circ} \mathrm{C}\right)\end{array}$ & $\begin{array}{c}\text { Flash } \\
\text { point } \\
\left.{ }^{\circ} \mathrm{C}\right)\end{array}$ & $\begin{array}{c}\text { Cetane } \\
\text { No. }\end{array}$ & $\begin{array}{c}\text { Viscosity } \\
\left(\mathrm{mm}^{2} / \mathrm{s} \text { at }\right. \\
\left.40^{\circ} \mathrm{C}\right)\end{array}$ & $\begin{array}{c}\text { Density } \\
\left(\mathrm{Kg} / \mathrm{m}^{3}\right)\end{array}$ & $\begin{array}{c}\text { Calorific } \\
\text { value (kJ/ } \\
\mathrm{kg})\end{array}$ \\
\hline $\begin{array}{c}\text { Diesel } \\
\text { fuel }\end{array}$ & $180-360$ & 59 & 52 & 2.72 & 840 & 42500 \\
\hline $\begin{array}{c}\text { Biodiesel } \\
\text { (B100) }\end{array}$ & - & 176 & 67 & 4.92 & 870 & 37000 \\
\hline \begin{tabular}{c} 
Octanol \\
\hline Pentanol
\end{tabular} & 137.9 & 49 & $18-20$ & 2.89 & 815 & 34650 \\
\hline
\end{tabular}


Table (3): Types of measurement with their accuracy for the current study

\begin{tabular}{|c|c|}
\hline Type of Measurement & Accuracy \\
\hline Temperature & $\pm 0.6 \%$ \\
\hline Fuel mass flow & $\pm 1 \%$ \\
\hline Air mass flow & $\pm 2 \%$ \\
\hline Engine speed & $\pm 1.3 \%$ \\
\hline Engine torque & $\pm 2.4 \%$ \\
\hline Concentrations of exhaust gases & $\pm 0.82 \%$ \\
\hline
\end{tabular}

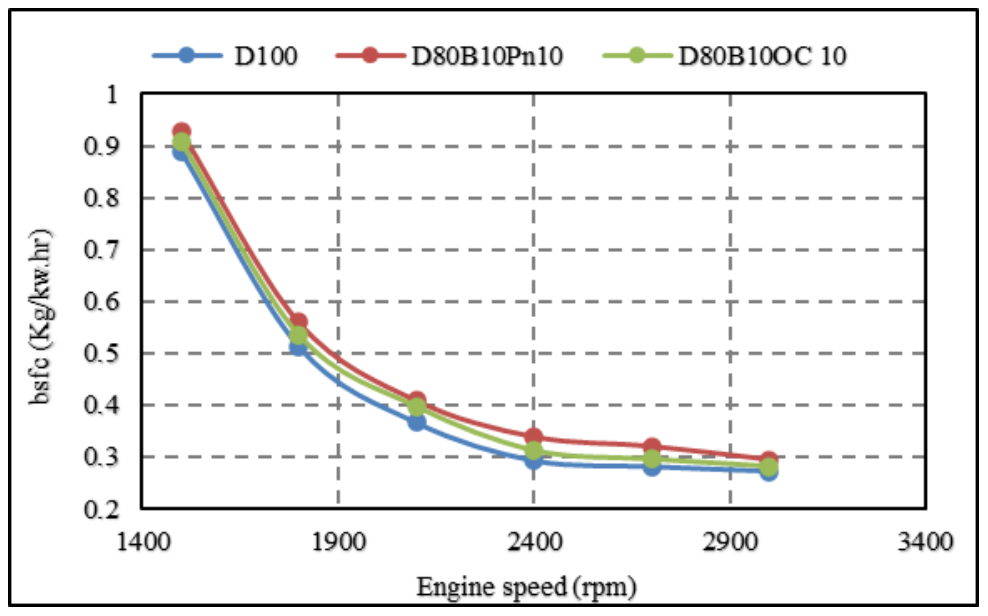

(a)

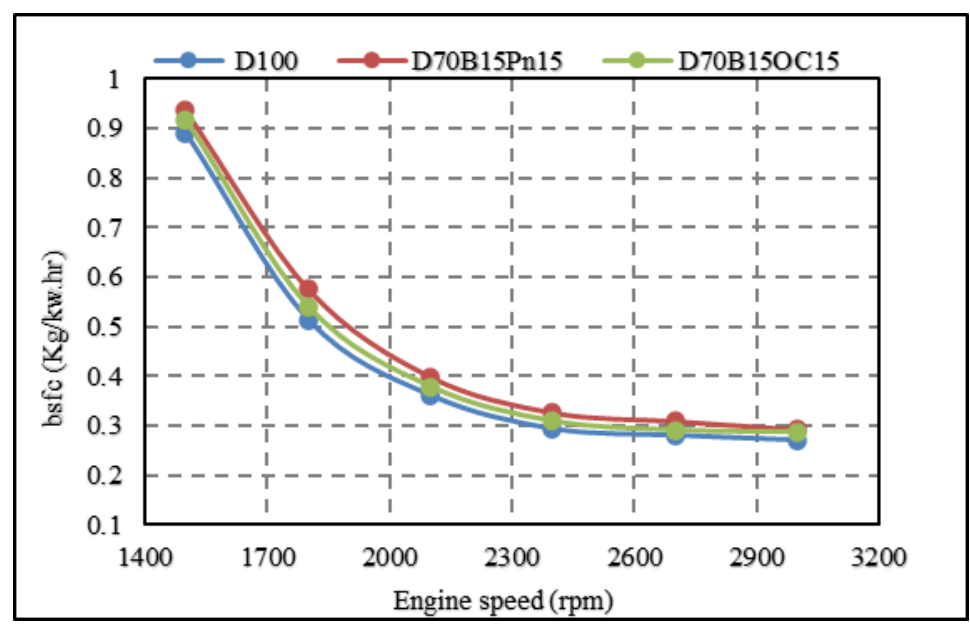

(b)

Fig.(2)Variation of brake specific fuel consumption with the engine speed at different fuel ratios. 


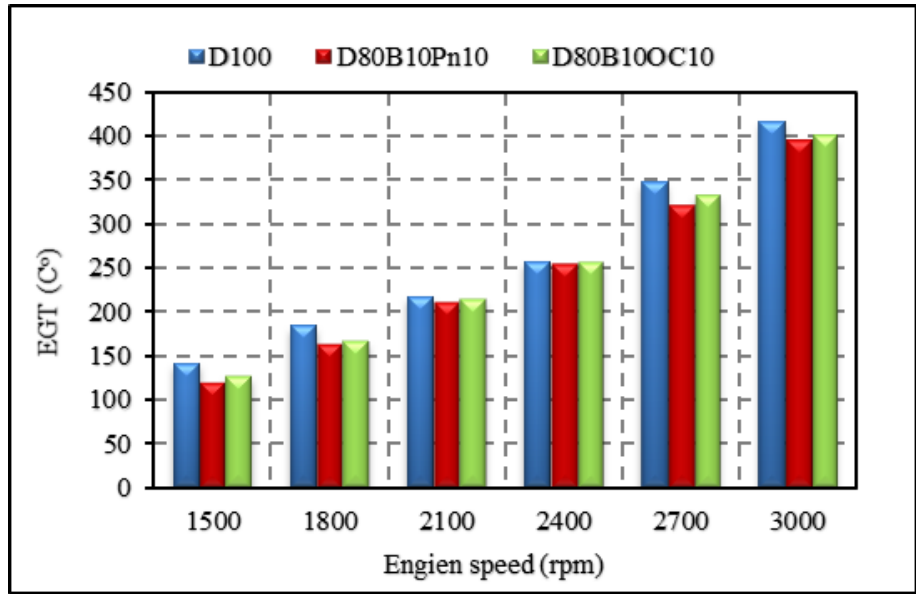

(a)

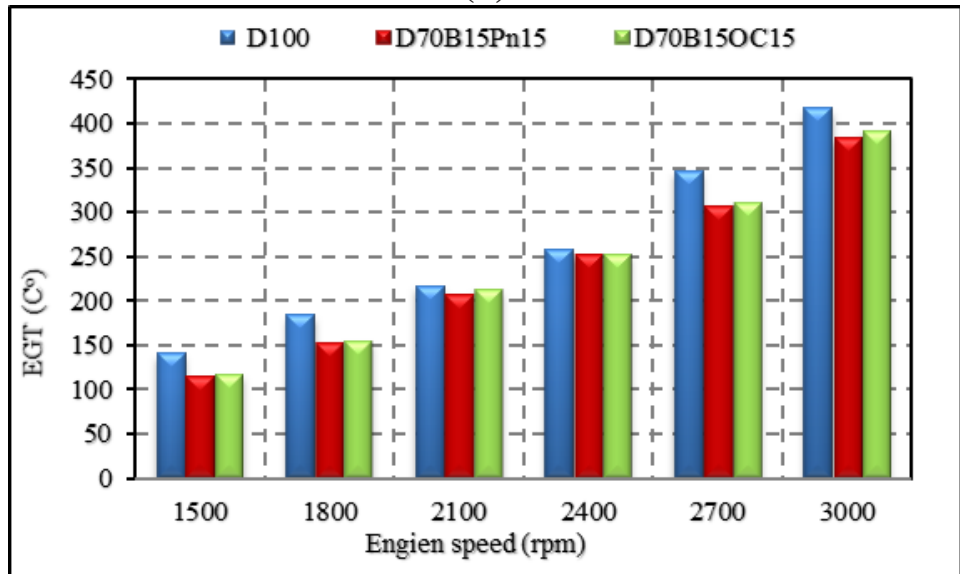

(b)

Fig. (3): Variation of exhaust gasses temperature with the engine speed at different fuel

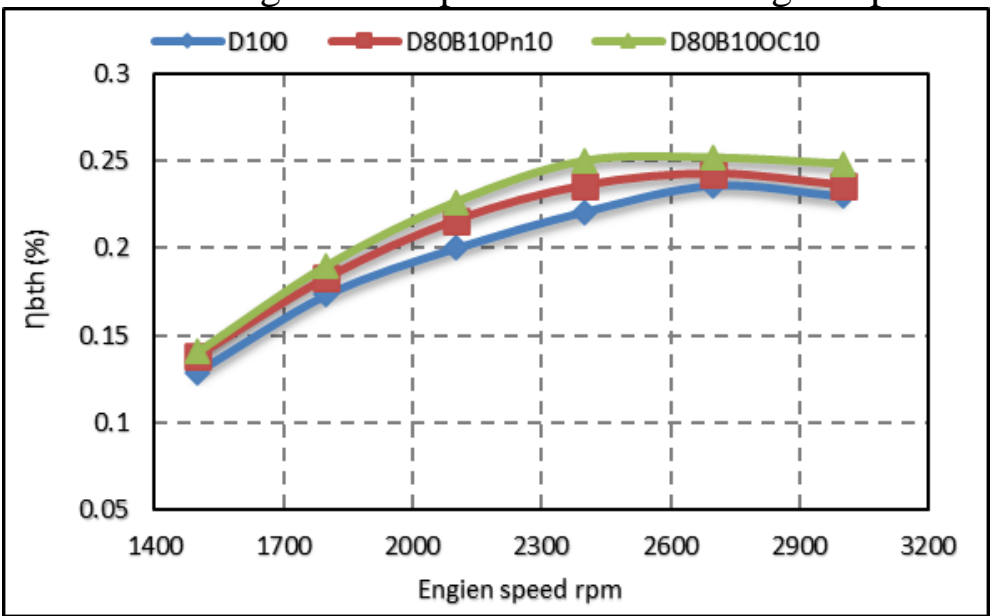

(a) 


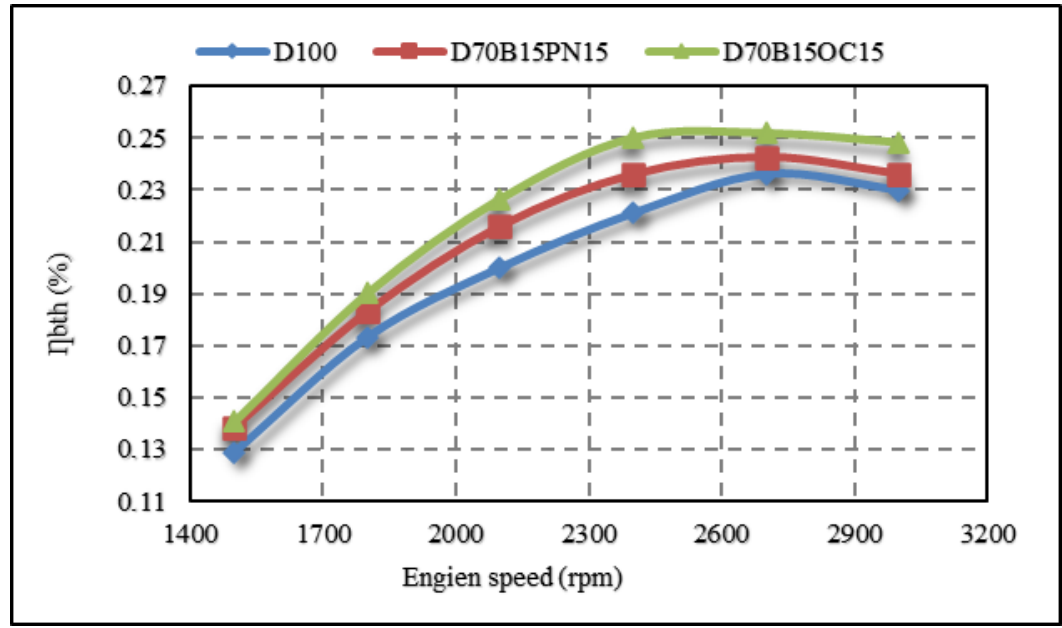

(b)

Fig.(4): Variation of brake thermal efficiency with the engine speed at different fuel blends.
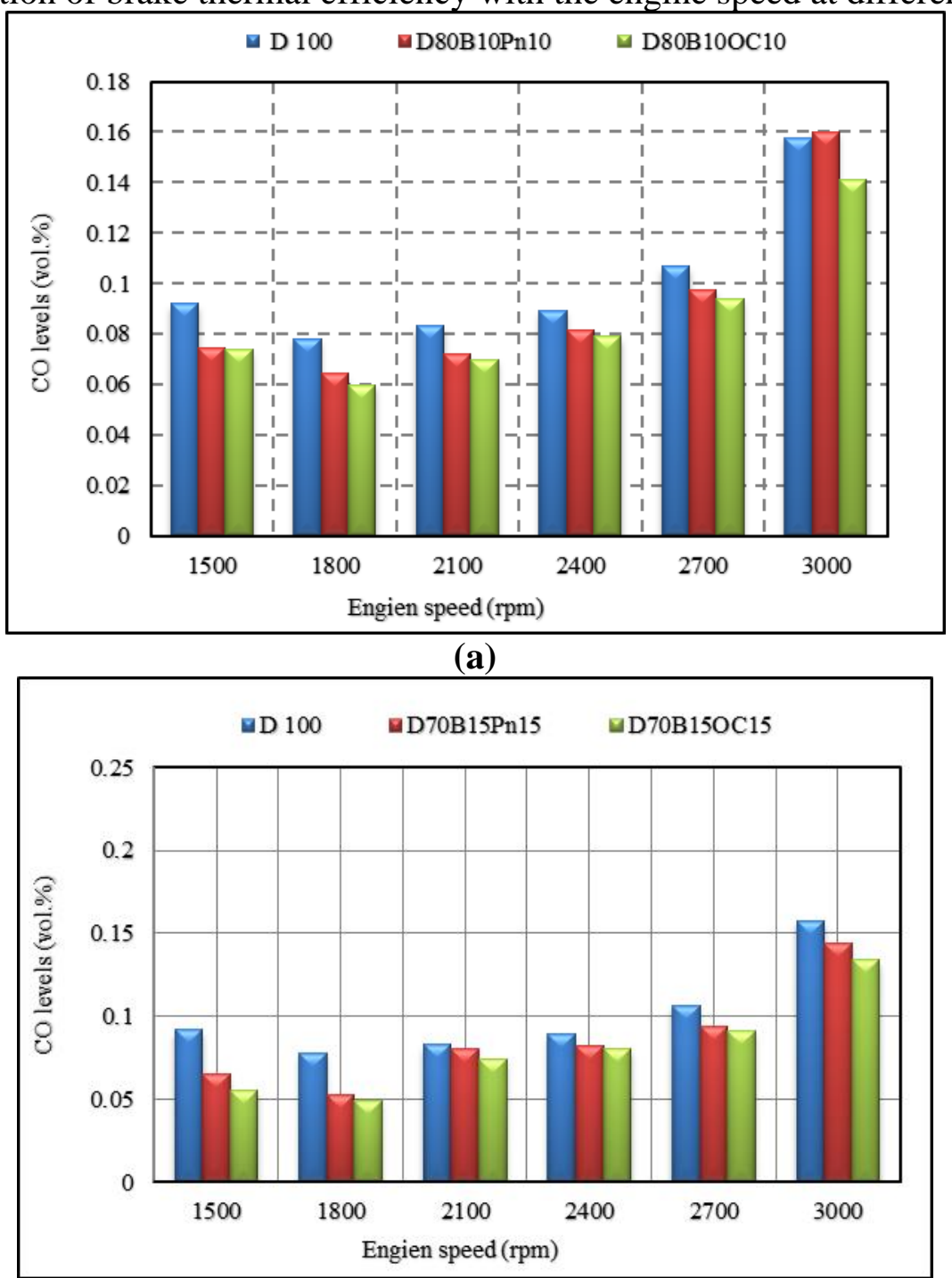

(b)

Fig. (5): Variation of $\mathrm{CO}$ emission with the engine speed at different fuel blends. 


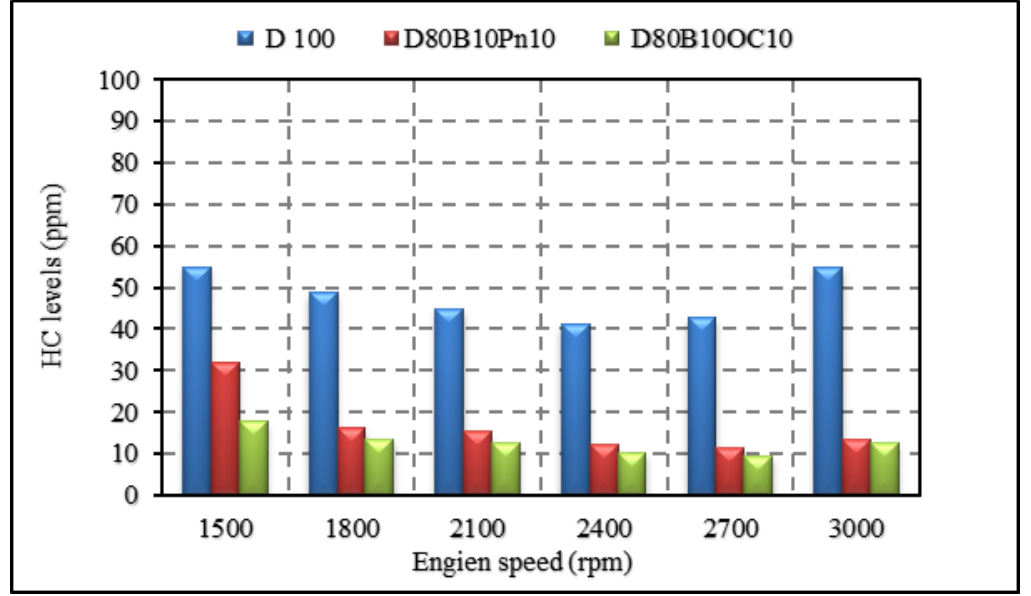

(a)

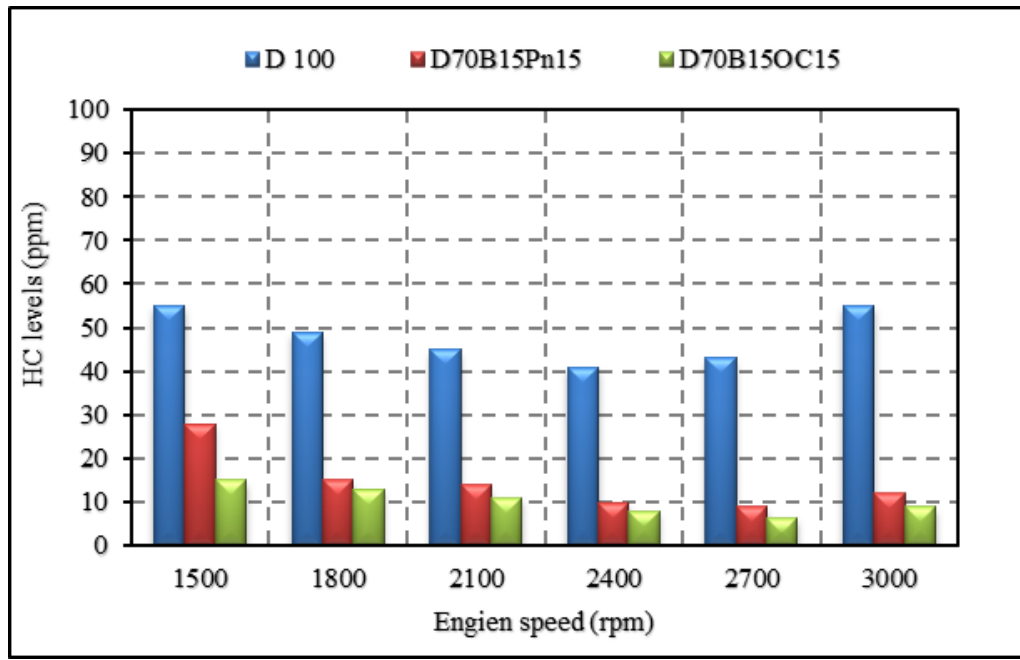

(b)

Fig. (6): Variation of $\mathrm{HC}$ emissions with the engine speed at different fuel blends.

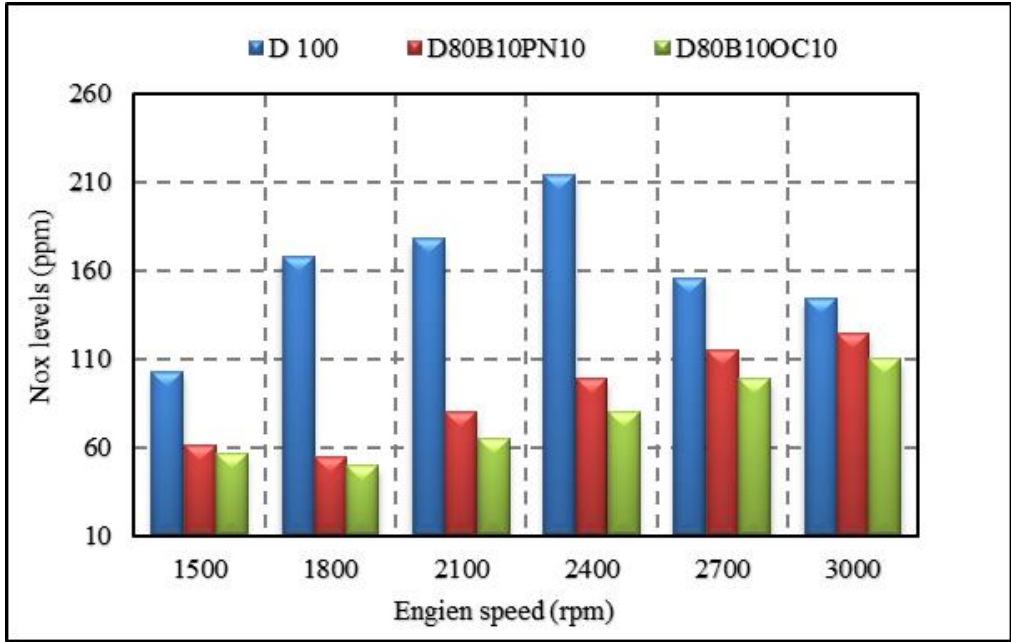

(a) 


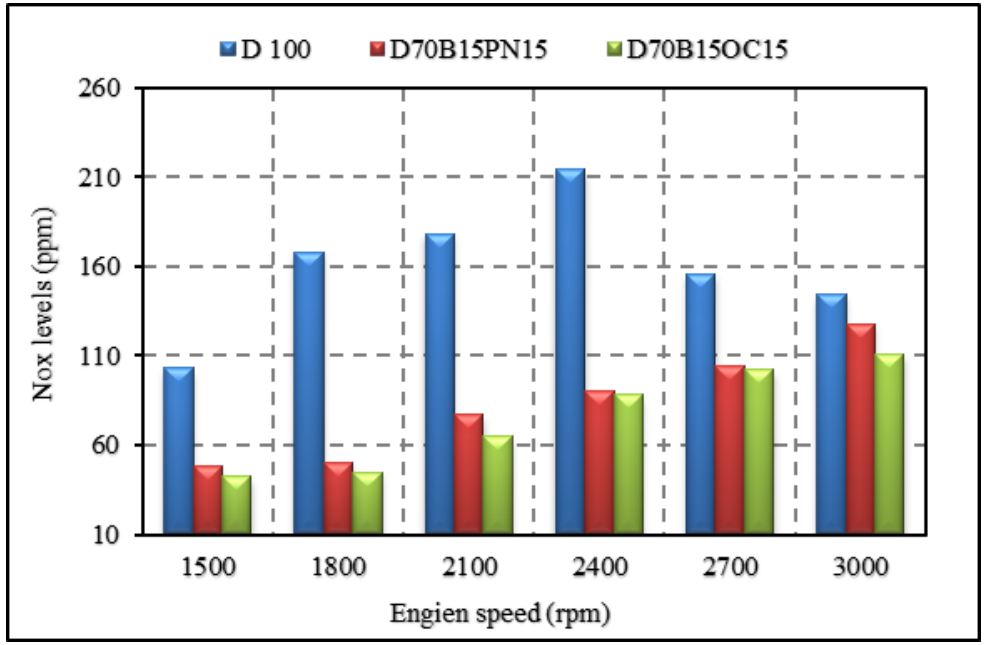

(b)

Fig. (7): Variation of $\mathrm{NO}_{\mathrm{X}}$ with the engine speed at different fuel blends.

\section{REFERENCES}

A.M. Liaquat*, H.H. Masjuki, M.A. Kalam, I.M. Rizwanul Fattah, M.A. Hazrat, M. Varman, M. Mofijur, M. Shahabuddin. 2013. "Effect of Coconut Biodiesel Blended Fuels on Engine Performance and Emission Characteristics." Procedia Engineering 56:583-90.

Altun, Şehmus, Cengiz Öner, Fevzi Yaşar, and Hamit Adin. 2011. "Effect of N-Butanol Blending with a Blend of Diesel and Biodiesel on Performance and Exhaust Emissions of a Diesel Engine.” Industrial and Engineering Chemistry Research 50(15):9425-30.

Chaichan, Miqdam Tariq. 2015. "Improvement of NOx-PM Trade-off in CIE Though Blends of Ethanol or Methanol and EGR." Iarjset 2(12):121-28.

Devarajan, Yuvarajan, Ravi kumar Jayabal, Devanathan Ragupathy, and Harish Venu. 2017. "Emissions Analysis on Second Generation Biodiesel." Frontiers of Environmental Science and Engineering 11(1):1-6.

Emiroğlu, A. Osman and Mehmet Şen. 2018. "Combustion, Performance and Exhaust Emission Characterizations of a Diesel Engine Operating with a Ternary Blend (AlcoholBiodiesel-Diesel Fuel)." Applied Thermal Engineering 133:371-80.

. Applied Combustion. edited by Taylor \&. Francis. 2007Second edition.

John B.Heywood. 1988. Internal Combustion Engine Fundamentals. 1st Editio. Milan: McGraw-Hill Series in Mechanical Engineering.

Li, Li, Jianxin Wang, Zhi Wang, and Haoye Liu. . "Combustion and Emissions of Compression Ignition in a Direct Injection Diesel Engine Fueled with Pentanol.” Enrgy Volume 80, 1 February 2015, Pages 575-581

Li, Li, Jianxin Wang, Zhi Wang, and Jianhua Xiao. 2015. "Combustion and Emission Characteristics of Diesel Engine Fueled with Diesel/Biodiesel/Pentanol Fuel Blends." Fuel Volume 156, 15 September 2015, Pages 211-218 
M. Sivakumar, N. Shanmugasundaram, R. Rameshkumar, M. Syed Thasthagir. 2016. "Effects of Pongamia Methyl Esters and Its Blends on a Diesel Engine Performance, Combustion, and Emission Characteristics." American Institute of Chemical Engineers.

Mingfa Yao, Hu Wang, Zunqing Zheng, Yan Yue. 2010. "Experimental Study of N-Butanol Additive and Multi-Injection on HD Diesel Engine Performance and Emissions." Fuel 89(9):2191-2201.

Rajesh Kumar, B. and S. Saravanan. 2015. "Effect of Exhaust Gas Recirculation (EGR) on Performance and Emissions of a Constant Speed Di Diesel Engine Fueled with Pentanol/Diesel Blends." Fuel 160(August):217-26.

Rajesh Kumar, B., S. Saravanan, D. Rana, V. Anish, and A. Nagendran. 2016. "Effect of a Sustainable Biofuel - n-Octanol - on the Combustion, Performance and Emissions of a DI Diesel Engine under Naturally Aspirated and Exhaust Gas Recirculation (EGR) Modes.” Energy Conversion and Management 118:275-86.

Saleh, Miqdam Tariq Chaichan Adel Mahmood. 2013. "PRACTICAL INVESTIGATION OF performance of single cylinder compression ignition engine fueled with duel fuel." The Iraqi Journal For Mechanical And Material Engineering 13(2):198-211.

Stephen R. Turns. 1996. An Introduction to Combustion. Thired edi.

Venkata Ramanan, M. and D. Yuvarajan. 2016. "Emission Analysis on the Influence of Magnetite Nanofluid on Methyl Ester in Diesel Engine." Atmospheric Pollution Research 7(3):477-81.

Wang, Xiangang, C. S. Cheung, Yage Di, and Zuohua Huang. 2012. "Diesel Engine Gaseous and Particle Emissions Fueled with Diesel-Oxygenate Blends.” Fuel 94:317-23.

Yasin, Mohd Hafizil Mat, Rizalman Mamat, Ahmad Fitri Yusop, Rafidah Rahim, Amir Aziz, and Liyana Amer Shah. 2013. "Fuel Physical Characteristics of Biodiesel Blend Fuels with Alcohol as Additives." Procedia Engineering 53:701-6.

Zhang, Zhi Hui and Rajasekhar Balasubramanian. 2014. "Influence of Butanol Addition to Diesel-Biodiesel Blend on Engine Performance and Particulate Emissions of a Stationary Diesel Engine.” Applied Energy 119:530-36. 